\title{
Assessment of Physicochemical Properties, Fatty Acid Composition of Afzelia africana Seed Oil and the Effect of Its Oil-Based Diet on Body Weight and Plasma Lipid Profile of Albino Rats
}

\author{
Itunu Oluwatosin Ajiboye, Olubunmi Bolanle Ajayi, Seun Funmilola Akomolafe, \\ Omotola Opeyemi Adelaja
}

Department of Biochemistry, Ekiti State University, Ado Ekiti, Nigeria

Email: bunmi_dave@yahoo.com

How to cite this paper: Ajiboye, I.O., Ajayi, O.B., Akomolafe, S.F. and Adelaja, O.O. (2018) Assessment of Physicochemical Properties, Fatty Acid Composition of Afzelia africana Seed Oil and the Effect of Its Oil-Based Diet on Body Weight and Plasma Lipid Profile of Albino Rats. Food and Nutrition Sciences, 9, 983-996.

https://doi.org/10.4236/fns.2018.98072

Received: July 28, 2018

Accepted: August 13, 2018

Published: August 16, 2018

Copyright $\odot 2018$ by authors and Scientific Research Publishing Inc. This work is licensed under the Creative Commons Attribution International License (CC BY 4.0).

http://creativecommons.org/licenses/by/4.0/

\begin{abstract}
In the present study, the physicochemical properties, fatty acid composition of Afzelia africana seed oil were determined and also effect of the oil-based diet on growth performance and plasma lipid profile were monitored using twenty Wistar albino rats allocated into two groups of ten rats each. The control group was fed with soybean-based diet while Afzelia africana oil-based diet was fed to the test group ad libitum for 28 days. Results showed the acid, saponification, iodine, and peroxide values of the oil to be $3.30 \pm 0.27 \mathrm{mg} / \mathrm{KOH} / \mathrm{g}$ oil, $124.54 \pm 0.79 \mathrm{mg} / \mathrm{KOH} / \mathrm{g}$ oil, $11.17 \pm 0.39 \mathrm{~g} / 100 \mathrm{~g}$, and $10.01 \pm 0.53 \mathrm{meq} / \mathrm{g}$ respectively. Also, linoleic (53\%) and oleic acids (21.34\%) were found to be the predominant unsaturated fatty acids present, while the predominant saturated fatty acid present is Palmitic acid (14.78\%). The body weight of the experimental rats maintained on diet formulated with Afzelia africana seed oil was reduced compared to the rats fed with control diet. The plasma concentration of triglycerides and high density lipoprotein was not significantly different $(\mathrm{p}<$ 0.05 ) in the two groups while the total cholesterol and low density lipoprotein concentration significantly decreased in the test group fed Afzelia africana oil-based diet. The decline in plasma total cholesterol levels suggests good quality of the oil. The various parameters investigated reveal the potentials of Afzelia africana seed oil and could serve as a good diet supplement.
\end{abstract}

\section{Keywords}

Afzelia africana, Fatty Acids, Oils, Lipid Profile, Physicochemical, Polyunsaturated Fatty Acids (PUFAs) 


\section{Introduction}

Afzelia africana plants are mostly cultivated in the Savannah, fringing forest and the drier parts of the forest regions of Africa. The tree is a widespread species with abroad rather open crown and massive branches (most readily recognized by the conspicuous hard blackish fruits), up to $30.5 \mathrm{~m}$ high and a girth up to 3 $\mathrm{m}$. It belongs to the family leguminosae and sub-family caesalpinaceae [1]. It is called Kawo, Apa, Akpalata and Gayoki by the Hausa, Yoruba, Igbo and Fulani speaking areas of Nigeria, respectively. Proximate analysis has shown that the oil seed is a rich source of protein, total carbohydrate and crude fat and potassium [2]. The seeds have waxy orange cup-like structure at their base and are used in Nigeria generally as soup thickening ingredient [3]. The link between dietary fats, especially edible oils and health has necessitated a growing research interest in many valuable oils [4]. Some edible oils such as almond and avocado oil are good sources of vitamin A and E; canola oil obtained from rapeseeds, flax seed oil and soybean oil contain high levels of omega-3 fatty acid which lowers the risk and predisposition to cardiovascular diseases [5]. It has been generally agreed among nutritionist that edible oils such as coconut oil and peanut oils should be avoided due to high content of saturated fatty acids [6]. Many researchers had carried out in-vitro analysis (proximate, mineral contents) on $A f$ zelia africana seeds but few researches had been done on the physicochemical properties of Afzelia africana oil and its plasma lipid profile. Thus, this study was carried out to assess the fatty acid composition, physicochemical properties of Afzelia africana seed oil and the effect of its oil-based diet on growth performance and plasma lipid profile of Wistar albino rats.

\section{Materials and Methods}

\subsection{Collection and Preparation of Afzelia africana Seed}

The seeds of Afzelia africana used in this research were purchased at Mgbidi, Agwu local government in Enugu State, Nigeria. The seeds were processed using the traditional method [7]. The seeds were roasted for about 15 to 20 minutes in a wide aluminum steel pan. The roasted seeds were cracked with the use of wooden pestle to remove the skin. The endosperm of the seeds were removed and grounded into powder using manual blender and electric blender. The processing resulted in a fine yellowish powder.

\subsection{Afzelia africana Seed Oil Extraction}

The Afzelia oil was extracted using the soxhlet extraction procedure [8]. The African oak flour was neatly packed into filter papers and tied neatly with white thread. They were placed in a thimble which was suspended above a round bottom flask containing the extraction solvent (n-Hexane) and below a condenser. The flask was heated to $50^{\circ} \mathrm{C}$. The solvent evaporates and moves up into the condenser where it is converted back to liquid which trickles into the extraction chamber through the sample and back into the boiling solvent. After 6 hours this 
cycle, the boiling flask content was removed and placed in the rotary evaporator which separates the Afzelia oil from the extracting solvent. The oil was afterwards collected into a clean bottle.

\subsection{Physicochemical Analyses}

The acid, saponification, peroxide value and iodine values of the various oil samples were determined by the official AOCS Peroxide Value (PV) method Cd 8 - 53 [9] [10].

\subsection{Iodine Value Determination}

A fat solution of $20 \mathrm{~g}$ of Afzelia oil was dissolved in $100 \mathrm{ml}$ of chloroform. $10 \mathrm{ml}$ of the oil solution was pipetted into a stopper bottle and $25 \mathrm{ml}$ of iodine monochloride was added. The stopper bottle was shaken thoroughly and placed in the dark for an hour. A blank solution was prepared with the oil solution replaced with $10 \mathrm{ml}$ of water. After an hour, the stopper bottles were rinsed with about $50 \mathrm{ml}$ of water and $10 \mathrm{ml}$ of potassium iodide solution was added. The resulting solution was titrated with standard thiosulphate. When the solution became pale straw, $1 \mathrm{ml}$ of starch solution was added and the titration continued until blue colouration formed with the starch solution disappeared. The titre values for the test and blank were used to calculate the iodine value.

$$
\text { Iodine Value }=(\text { Blank }- \text { Test }) \times 6.35
$$

\subsection{Acid Value Determination}

$10 \mathrm{~g}$ of Afzelia oil was weighed into a beaker. $50 \mathrm{ml}$ of fat solvent was pipetted into the oil. $1 \mathrm{ml}$ of phenolphthalein solution was added and mixed thoroughly. The solution was titrated with $0.1 \mathrm{M} \mathrm{KOH}$ until faint pink colour persisted for 20 seconds. The titration was done in duplicate and the acid value was calculated as follows:

$$
\text { Acid Value }=\frac{\text { titre value } \times 5.6}{\log (\text { weight of sample })}
$$

\subsection{Saponification Value Determination}

$5 \mathrm{~g}$ of Afzelia oil was weighed into a conical flask. $50 \mathrm{ml} 0.5 \mathrm{M}$ of alcoholic $\mathrm{KOH}$ was added to the oil. A blank was prepared by dispensing $50 \mathrm{ml}$ of $0.5 \mathrm{M}$ alcoholic $\mathrm{KOH}$ with a blank solution into another conical flask. A reflux condenser was connected to each flask and was boiled for an hour. When the flask and condenser cooled, the inside of the condenser was rinsed with little distilled water and was removed. $1 \mathrm{ml}$ of phenolphthalein indicator was added into each flask and titrated against $0.5 \mathrm{M} \mathrm{HCl}$ until pink color disappeared. The titre value was taken and the saponification value was calculated thus:

$$
\text { Saponification Value }(\mathrm{mg} / \mathrm{g})=\frac{\text { Blank titre value }- \text { Sample titre value } \times 28.05}{\text { weight of sample }}
$$




\subsection{Peroxide Value Determination}

$5 \mathrm{~g}$ of Afzelia oil was weighed into clean dry boiling tube. $1 \mathrm{~g}$ of powdered potassium iodide and $2 \mathrm{ml}$ of solvent mix was added. The boiling tube was transferred into a water bath containing boiling water and left there to boil vigorously for 30 seconds. The content after 30 seconds of boiling was transferred into a conical flask containing $20 \mathrm{ml}$ of $5 \% \mathrm{KI}$ solution. The resulting solution was titrated with $0.1 \mathrm{M} \mathrm{Na}_{2} \mathrm{~S}_{2} \mathrm{O}_{3}$ solution until its yellow colour almost disappeared. $0.5 \mathrm{ml}$ of starch solution was added and shaken vigorously after which the titration continued until its blue colouration disappeared. The blank was set up without the oil sample at the same time. The titre value was taken and peroxide value was calculated using the formula below:

Peroxide Value $($ mmol peroxide $/ \mathrm{kg}$ sample $)=\frac{\text { Titre value } \times \text { Molarity of } \mathrm{Na}_{2} \mathrm{~S}_{2} \mathrm{O}_{3}}{\text { weight of sample }}$

\subsection{Experimental Animals}

Twenty (20) male weaning Wistar albino rats were obtained from the animal house, Department of Biochemistry, University of Ilorin, Kwara state, Nigeria. The animals had an initial weight ranging from $40-55 \mathrm{~g}$ and were kept under standard environmental conditions and were acclimatized for four (4) days. They were fed grower's mash and clean water ad libitum for the period of acclimatization before the introduction of formulated diet for 28 days.

\subsection{Experimental Diet Formulation}

\subsubsection{Control Diet}

Soybean oil was used for the control diet formulation. Other constituents includes corn-starch, casilan (protein source), sugar, vitamin-mineral mix and rice bran (fiber) were weighed and mixed together thoroughly by adding little quantity of water after which it was molded into pellets and sun-dried.

\subsubsection{Test Diet}

Afzelia africana seed oil served as the test ingredient was used to replace soybean oil while maintaining other similar constituents as the control diet.

The experimental diets for the control and test groups were formulated as shown in Table 1 . The mixtures were pelletized and properly dried.

Table 1. Experimental diet formulation.

\begin{tabular}{ccc}
\hline Ingredients & Control & Test \\
\hline Corn-starch (carbohydrate) & $\mathbf{5 6 0}$ & $\mathbf{5 6 0}$ \\
Casilan (protein source) & 200 & 200 \\
Vitamin-mineral mix & 50 & 50 \\
Sucrose & 100 & 100 \\
Cellulose (rice bran) & 40 & 40 \\
Afzelia africana seed oil & - & 50 \\
Soybean oil & 50 & -
\end{tabular}




\subsection{Experimental Procedure}

After the experimental animals were subjected to acclimatization for four (4) days, they were randomly sorted into one control group and a test group of ten (10) rats each.

- Control group; fed soybean oil-based diet.

- Test group; fed Afzelia africana oil-based diet.

\subsection{Collection of Blood and Plasma Preparation}

After 28 days of experimental feeding, the experimental rats were anaesthetized with chloroform and quickly dissected. Blood was collected via cardiac puncture into lithium-heparin bottles. The blood samples collected were centrifuged at $2500 \mathrm{rpm}$ for 10 minutes and the plasma was separated and was stored in a freezer at $4^{\circ} \mathrm{C}$ until required for analysis.

\subsection{Lipid Profile Assay}

Plasma total cholesterol, HDL cholesterol, and triglycerides were measured on the Hitachi 911 automated analyzer using reagent kits supplied by Roche Diagnostics (Laval, QC, Canada). The precision performance of these assays was within the manufacturer's specifications. LDL cholesterol was calculated by the Friedewald equation [11].

\subsection{Plasma Total Cholesterol Determination}

Cholesterol was determined after enzymatic hydrolysis and oxidation. The indicator 4-aminoantipyrine was formed from hydrogen peroxide and 4-aminoantipyrine in the presence of phenol and peroxidase [12]. A blank was prepared consisting of $1 \mathrm{ml}$ of R1 with $10 \mu \mathrm{l}$ of distilled water. For the standard, $10 \mu \mathrm{l}$ of the standard cholesterol solution and $1 \mathrm{ml}$ of $\mathrm{R} 1$ were prepared into clean test tubes. For the test, $10 \mu \mathrm{l}$ of the sample plasma and $1 \mathrm{ml}$ of $\mathrm{R} 1$ were pipetted into clean tube labelled sample. The tubes were shaken to mix the solution properly and were incubated at $37^{\circ} \mathrm{C}$ for 5 minutes. After incubation, the absorbance of the standard and tests were read against the blank at wavelength $546 \mathrm{~nm}$. The concentration of cholesterol in the sample was calculated thus:

$$
\begin{aligned}
& \text { Concentration of Cholesterol }(\mathrm{mmol} / \mathrm{l}) \\
& =\frac{\text { Absorbance of sample }}{\text { Absorbance of standard }} \times \text { Concentration of standard }
\end{aligned}
$$

\subsection{Plasma Triglyceride Determination}

Serum triglyceride levels were determined after enzymatic hydrolysis with lipases. The indicator is a quinoneimine formed from hydrogen peroxide, 4 -aminoph enazone and 4-chlorophenol under the catalytic influence of peroxidase. R1b was reconstituted with $15 \mathrm{ml}$ of R1a to form the working reagent. $1 \mathrm{ml}$ of the working reagent was pipetted in labelled tubes of blank, standard and samples. $10 \mu \mathrm{l}$ of the standard solution and $10 \mu \mathrm{l}$ of the samples were pipetted into the 
standard and samples test tubes respectively. All the test tubes were incubated at $37^{\circ} \mathrm{C}$ for five minutes after which the absorbance of the standard and the samples were read against the blank at wave length $546 \mathrm{~nm}$ using a spectrophotometer [13].

$$
\begin{aligned}
& \text { Concentration of Triglycerides }(\mathrm{mmol} / \mathrm{l}) \\
& =\frac{\text { Absorbance of sample }}{\text { Absorbance of standard }} \times \text { Concentration of standard }
\end{aligned}
$$

\subsection{High Density Lipoprotein Determination in Plasma}

Low density lipoprotein (LDL and VLDL) and chylomicrons fractions were precipitated quantitatively by the addition of phosphotungstic acid in the presence of magnesium ions. After centrifugation, the cholesterol concentration in the HDL fraction which remains in the supernatant was determined. $500 \mu \mathrm{l}$ of R1 was dispensed into test tubes labelled blank, standard and samples. $200 \mu \mathrm{l}$ of standard cholesterol and $200 \mu \mathrm{l}$ of sample plasma were pipetted into the standard and samples test tubes respectively. The tubes were centrifuged at $2500 \mathrm{rpm}$ for five minutes. After centrifugation, $200 \mu \mathrm{l}$ of the supernatant were dispensed into another set of labelled tubes accordingly after which $2 \mathrm{ml}$ of cholesterol reagent was added. They were incubated for ten minutes at $37^{\circ} \mathrm{C}[14]$.

The absorbance of the sample and standard were determined against the blank at $546 \mathrm{~nm}$ using a spectrophotometer.

$$
\begin{aligned}
& \text { Concentration of HDL in sample }(\mathrm{mmol} / \mathrm{l}) \\
& =\frac{\text { Absorbance of sample }}{\text { Absorbance of standard }} \times \text { Concentration of standard }
\end{aligned}
$$

\subsection{Low Density Lipoprotein Determination in Plasma}

The amount of LDL-cholesterol was calculated using the results of a standard lipid profile which consist of total cholesterol, high density lipoprotein and triglycerides [11].

Low density lipoprotein $(\mathrm{mmol} / \mathrm{l})=$ cholesterol $-\left(\frac{\text { triglycerides }}{2}-\mathrm{HDL}\right)$

\subsection{Statistical Analysis}

Data obtained were subjected to Duncan's Multiple Range Test [15] following One-Way Analysis of Variance (ANOVA), using SPSS 20 statistical package. Data were expressed as mean \pm standard deviation and differences at $\mathrm{p}<0.05$ were considered significant.

\section{Results and Discussion}

The physicochemical properties of Afzelia africana seed oil are shown in Table 2.

The acid value in $\mathrm{mg} / \mathrm{KOH} / \mathrm{g}$ for Afzelia africana seed oil was 3.30 and this 
value relates with the values of 3.0, 2.5, for sunflower and coconut oil respectively used as edible and industrial oil [16]. This value almost corresponds with the value of 3.37 as reported by previous studies [17] for Afzelia africana seed oil. This low level of free fatty acids is an indication that the components were predominantly composed of triacylglycerol and presence of natural antioxidants [18]. The lower the free fatty acid content, the more appealing the oil is [19]. Saponification value helps to ascertain the presence of fixed oil in vegetable oils.

Saponification values also represent the molecular weight of oil [20]. Afzelia africana oil saponification value in $\mathrm{mg} / \mathrm{KOH} / \mathrm{g}$ was 124.54 , close to $128 \mathrm{mg} / \mathrm{KOH} / \mathrm{g}$ oil [17] for Afzelia africana oil and $128.480 \mathrm{mg} / \mathrm{KOH} / \mathrm{g}$ oil obtained by previous studies for African pear and by far higher than the $52.11 \mathrm{mg} / \mathrm{KOH} / \mathrm{g}$ oil [21] [22].

Iodine value indicates the drying quality of oil. Dry oil shows higher iodine value [20]. The iodine value was found to be $11.17 \mathrm{~g} / 100 \mathrm{~g}$, this indicates that it is non-drying oil [23] and such oils are liquid at room temperature. These non-drying oils are very useful in the manufacturing of soaps, lubricants and food. However, the values obtained were lower than that obtained in other studies [17] for Afzelia africana oil.

Peroxide value is a common method used to measure lipid oxidation, and is suitable for measuring peroxide formation in the early stages of oxidation [24]. Unsaturated fatty acids presence will easily react with oxygen to form peroxides [25]. The peroxide value was $10.1 \mathrm{meq} / \mathrm{kg}$ which is related to the standard value of $10 \mathrm{meq} / \mathrm{kg}$ specified by Nigerian regulatory bodies [26] [27]. Similar lower peroxide values of less than 10 were observed in canola oil, corn oil, coconut oil, grape seed oil, olive oil, palm-olein, peanut oil, rapeseed oil, rice bran oil, sunflower oil, soybean oil, sesame oil, safflower oil and walnut oil [28].

The percentage fatty acid composition of Afzelia africana seed oil shown in Table 3 reveals that the oil contains $56.43 \%$ polyunsaturated, $22.63 \%$ monounsaturated and $20.94 \%$ saturated fatty acids.

The fatty acid profile of fats and oils has a large bearing on their quality. The fatty acid profile affects the shelf-life, flavor and the stability of the oil. From the results obtained, it is observable that Afzelia africana seed oil is a good source of essential fatty acids. Behenic acid is a cholesterol-raising saturated fatty acid in humans [29]. Stearic acid is less likely to be incorporated into cholesterol esters. In epidemiologic and clinical studies, stearic acid was found to be associated with lowered LDL cholesterol in comparison with other saturated fatty acids [30]. According to the World Health Organization, evidence is convincing that consumption of palmitic acid increases the risk of developing cardiovascular disease [31] based on studies indicating that it may increase LDL levels in the blood. Retinyl palmitate is an antioxidant and a source of vitamin A added to low fat milk to replace the vitamin content lost through the removal of milk fat. Palmitate is attached to the alcohol form of vitamin A, retinol, to make vitamin A stable in milk. 
Table 2. Physicochemical properties of Afzelia africana Seed oil.

\begin{tabular}{cc}
\hline Parameters & Results \\
\hline Acid value $(\mathrm{mg} / \mathrm{KOH} / \mathrm{g})$ & $3.30 \pm 0.27$ \\
Saponification value $(\mathrm{mg} / \mathrm{KOH} / \mathrm{g})$ & $124.54 \pm 0.79$ \\
Iodine value $(\mathrm{g} / 100 \mathrm{~g})$ & $11.17 \pm 0.39$ \\
Peroxide value $(\mathrm{meq} / \mathrm{g})$ & $10.10 \pm 0.53$ \\
\hline
\end{tabular}

Data are mean \pm standard deviation of two determinations.

Table 3. Percentage fatty acid composition of Afzelia africana seed oil.

\begin{tabular}{cc}
\hline Fatty acids & Afzelia africana oil (\%) \\
\hline Saturated fatty acids & 14.78 \\
Palmitic acid $\left(\mathrm{C}_{16: 0}\right)$ & 5.21 \\
Stearic acid $\left(\mathrm{C}_{18: 0}\right)$ & 0.55 \\
Arachidic acid $\left(\mathrm{C}_{20: 0}\right)$ & 0.40 \\
Behenic acid $\left(\mathrm{C}_{22: 0}\right)$ & \\
Monounsaturated fatty acids & 1.29 \\
Palmitoleic acid $\left(\mathrm{C}_{16: 1}\right)$ & 21.34 \\
Oleic acid $\left(\mathrm{C}_{18: 1}\right)$ & \\
Polyunsaturated fatty acids & 53.46 \\
Linoleic acid $\left(\mathrm{C}_{18: 2}\right)$ & 2.97 \\
Linolenic acid $\left(\mathrm{C}_{18: 3}\right)$ &
\end{tabular}

Rats fed a diet of $20 \%$ palmitic acid and $80 \%$ carbohydrate for extended periods showed alterations in central nervous system control of insulin secretion, and suppression of the body's natural appetite-suppressing signals for leptin and insulin (the key hormones involved in weight regulation) [32]. Palmitic acid strongly boosts metastasis in mouse models of human oral cancer cells. Among all fatty acids, it has the strongest effect in boosting the metastatic potential of CD36 + metastasis-initiating cells [33].

Linoleic acid (53.46\%) and linolenic acid (2.97\%) are polyunsaturated fatty acids that possess favorable nutritional implications and health benefits, such as regulating blood cholesterol levels, lowering elevated blood pressure and beneficial physiological effects in the prevention of coronary heart disease and cancer [34]. Linoleic Acid is used in the biosynthesis of arachidonic acid (AA) and thus some prostaglandins, leukotrienes (LTA, LTB, LTC), and thromboxane (TXA). It is found in the lipids of cell membranes. It is abundant in many nuts, fatty seeds (flax seeds, hemp seeds, poppy seeds, sesame seeds, etc.) and their derived vegetable oils; comprising over half (by weight) of poppy seed, safflower, sunflower, corn, and soybean oils [35].

High ratio polyunsaturated/saturated fatty acids are regarded favorably in the reduction of the serum cholesterol and atherosclerosis and the prevention of heart diseases [36] [37]. Polyunsaturated/saturated fatty acids ratio of Afzelia africana oil was 2.69. The appreciable concentration of oleic acid in the vegetable oils makes them desirable in terms of nutrition [38] and Afzelia africana seed oil 
has an appreciable amount of $21.34 \%$. The ratio of oleic to linoleic acid is a measure of oil stability [39], and it is a critical factor in determining oil quality [40]. The oil contained a low percentage of palmitic acid which is a natural antioxidant. Together with the high level of polyunsaturated fatty acids and low antioxidant capacity, it is an indicative of poor oxidative stability and would require antioxidant to prevent quick deterioration.

\section{Growth performance of albino rats fed Afzelia africana-based diets}

The mean body weights of the rats fed Afzelia Africana seed oil-based diet are shown in Table 4.

According to the results, the test group has significant decreased $(\mathrm{p}<0.05)$ compared to the control group. Feed gain ratio also known as feed conversion rate or feed conversion efficiency (FCE), feed conversion ratio (FCR) is a measure of an animal's efficiency in converting feed mass into increases of mass gained by the animal. A low FCR is a good indication of a high quality feed [41]. The result correlates with the report of previous works which showed that rats fed with Afzelia africana flour, had lower body weight gain when compared with the control group fed with soybean oil [42]. The low feed intake could be due to the taste and/or texture of these diets [43] that taste and texture of finished feeds influence intake in animals.

The result of the plasma lipid profile of animals fed Afzelia africana oil-based diet is presented in Table 5 .

Table 4. Growth performance of albino rats fed Afzelia africana oil-based diet.

\begin{tabular}{ccc}
\hline & Control rats (A) & Test rats (B) \\
\hline Final weight $(\mathrm{g})$ & $113.49 \pm 4.07^{\mathrm{a}}$ & $102.98 \pm 9.4^{\mathrm{b}}$ \\
Initial weight $(\mathrm{g})$ & $50.76 \pm 6.2^{\mathrm{a}}$ & $52.91 \pm 6.8^{\mathrm{a}}$ \\
Weight gain $(\mathrm{g})$ & 62.73 & 50.07 \\
Feed intake per day (g) & $70.77 \pm 33.9^{\mathrm{a}}$ & $69.62 \pm 37.5^{\mathrm{a}}$
\end{tabular}

Results are expressed as mean \pm SD $(n=10)$; values for the test in the same row for each parameter with superscript different from the control are significantly different at $\mathrm{p}<0.05$.

Table 5. Plasma lipid profile of albino rats fed Afzelia africana oil-based diet.

\begin{tabular}{ccc}
\hline Parameters & Control $(\mathrm{A})$ & Test (B) \\
\hline Total cholesterol $(\mathrm{mmol} / \mathrm{l})$ & $3.4 \pm 0.62^{\mathrm{a}}$ & $2.0 \pm 0.29^{\mathrm{b}}$ \\
Triglycerides $(\mathrm{mmol} / \mathrm{L})$ & $1.2 \pm 0.63^{\mathrm{a}}$ & $0.84 \pm 0.15^{\mathrm{a}}$ \\
High density lipoprotein $(\mathrm{mmol} / \mathrm{l})$ & $1.24 \pm 0.55^{\mathrm{a}}$ & $0.88 \pm 0.05^{\mathrm{a}}$ \\
Low density lipoprotein $(\mathrm{mmol} / \mathrm{l})$ & $1.61 \pm 0.42^{\mathrm{a}}$ & $0.64 \pm 0.14^{\mathrm{b}}$ \\
LDL/HDL & 1.29 & 0.73 \\
TC/HDL & 2.74 & 2.27 \\
\hline
\end{tabular}

Results are expressed as mean \pm SD; values for the test in the same row for each parameter with superscript different from the control are significantly different at $\mathrm{p}<0.05$. 
It reveals that there is no significant difference in the values of triacylglycerol and HDL-C both in the test and control group while LDL-C and total cholesterol had a significant difference in the test and control group. HDL-C transports cholesterol from peripheral tissues to the liver for elimination [44]. HDL-C in this result shows a slight decrease $1.24 \mathrm{mmol} / \mathrm{l}$ and $0.88 \mathrm{mmol} / \mathrm{l}$ (control and test group respectively) which is in agreement with previous research reports [44] [45]. Increase in LDL-C has been pointed out as one of the risk factors for the development of atherosclerosis and related cardiovascular diseases [46]. The result shows a significant decrease in the test group $(0.64 \mathrm{mmol} / \mathrm{l})$ when compared to the control group $(1.61 \mathrm{mmol} / \mathrm{l})$. It has been reported that the relative content of saturated and poly unsaturated fatty acids (PUFA) in the diet affects plasma level of cholesterol [47]. Polyunsaturated Fatty Acids (PUFA) are well known for their anti-inflammatory and insulin-sensitizing properties, and also cause hypolipidemia [48].

Polyunsaturated fats stimulate the catabolic rate of LDL-cholesterol, thus resulting in the reduction of serum LDL-cholesterol [49]. Although metabolic studies have shown that consumption of n-6 PUFA lowers circulating cholesterol level [50]. The high content of $\alpha$-linolenic acid may play an important role in decreasing the risk of coronary heart disease (CHD) by lowering levels of low-density lipoprotein cholesterol, as reported [51]. Low levels of saturated fatty acid (SFA) as palmitic acid $\left(\mathrm{C}_{16: 0}\right)$, may be another protective factor against CHD [52].

Triglycerides (TG) which function as blood lipid helps enable the bi-directional transference of adipose fat and blood glucose from the liver. There was slight significant difference between the test group $(0.84 \mathrm{mmol} / \mathrm{l})$ and control group $(1.2 \mathrm{mmol} / \mathrm{l})$. This is an indication that Afzelia africana oil does not increase blood triglycerides. Plasma total cholesterol (TC) of the test group is lower than the control group. It has been previously shown that constituents of soybean oil, such as $\alpha$-linoleic acid, are capable of reducing cholesterol in hypercholesterolemic patients [53]. With Afzelia africana seed oil (53.46\%) having almost the same amount of soybean oil $\alpha$-linoleic acid (53.94\%) as previously shown by previous research [54], had a significant effect in lipid profile with a significant reduction of plasma triglycerides, cholesterol and phospholipid levels. Linoleic in soybean oil significantly reduced both total and non-HDL serum cholesterol and triglycerides induced by atherogenic diet [55].

\section{Conclusion}

This study recommends Afzelia africana seed oil as a good source of unsaturated fatty acids and as such, dietary supplementation and consumption of Afzelia africana seed oil could be beneficial to human health.

\section{Conflict of Interests}

No competing financial interests exist. 


\section{References}

[1] Keay, R.W., Onochie C.F. and Stanfield, D.P. (1964) Nigerian Trees. National Press Ltd., Forestry Research Institute of Nigeria, Ibadan, 47.

[2] Onweluzo, J.C., Onuoha, K.C. and Obanu, Z.A. (1995) A Comparative Study of Some Functional Properties of Afzelia africana and Glycine Max Flours. Food Chemistry, 54, 55-59. https://doi.org/10.1016/0308-8146(95)92662-4

[3] Igwenyi, I.O. and Akubugwo, E.I. (2010) Analysis of Four Seeds Used as Soup Thickeners in the South Eastern Parts of Nigeria. Kyoto International Conference Centre, Kyoto, 426-430.

[4] Eidangbe, G.O., Ojeih, G.C., Idonije, B.O. and Oluba, O.M. (2010) Palm Oil and Egusi Melon Oil Lower Serum and Liver Lipid Profile and Improve Antioxidant in Rats Fed a High Fat Diet. Journal of Food Technology, 8, 154-158. https://doi.org/10.3923/jftech.2010.154.158

[5] Arterburn, L.M., Oken, H.A., Bailey, H.E., Hamersley, J., Kuratko, C.N. and Hoffman, J.P (2008) Algal-Oil Capsules and Cooked Salmon: Nutritionally Equivalent Sources of Docosahexaenoic Acid. Journal of the Academy of Nutrition and Dietetics, 108, 1204-1209. https://doi.org/10.1016/j.jada.2008.04.020

[6] Enig, M.G. (1996) Health and Nutritional Benefits from Coconut Oil: An Important Functional Food for the 21st Century. The Seminar A VOC Lauric Oils Symposium, Ho Chi Min City, 25 April 1996.

[7] Onyechi, U.A. (1995) Potential Role of Indigenous Nigeria Food in the Treatment of Non-Insulin Dependent Diabetes Mellitus. Ph.D. Thesis, University of London, London.

[8] Harwood, L.M. and Moody, C.J. (1989) Experimental Organic Chemistry: Principles and Practice (Illustrated Edition). Wiley-Blackwell, Hoboken, 122-125.

[9] AOCS (2004) Official Methods and Recommended Practices of the American Oil Chemists' Society. 5th Edition, Champaign.

[10] Ibitoye, A.A. (2005) Laboratory Manual of Basic Methods in Analytical Chemistry. 1st Edition, Concept + IT and Educational Consult, Akure.

[11] Friedewal, W.T., Levy, I.T. and Fredrickson, D.S. (1972) Estimation of the Concentration of Low-Density Lipoprotein Cholesterol in Plasma, without Use of Preparative Ultracentrifuge. Clinical Chemistry, 18, 499-502.

[12] Trinder, P. (1964) Determination of Glucose in Blood Using Glucose Oxidase with an Alternative Oxygen Acceptor. Annals of Clinical Biochemistry, 6, 24-27. https://doi.org/10.1177/000456326900600108

[13] NIHP (National Institute of Health Publication) (2001) ATP III Guidelines At-a-Glance Quick Desk Reference. National Cholesterol Education Program, No. 01-3305.

[14] Izawa, S., Okada, M., Matsui, H. and Horita, Y.J. (1997) Quantitative Determination of HDL Cholesterol IVD. Medicine and Pharmaceutical Science, 37, 1385-1388.

[15] Harris, J., Loftis, J.C. and Montgomery, R.H. (1987) Statistical Methods for Characterizing Ground-Water Quality. Groundwater, 25, 185-193. https://doi.org/10.1111/j.1745-6584.1987.tb02875.x

[16] Engler, C.R. and Johnson, L.A. (1983) Effects of Processing on the Quality of Cashew Nuts. Journal of Science and Agriculture, Food Technology and Environment, 4, 105-110.

[17] Ejikeme, P.M., Obasi, L.N. and Egbuonu, A.C. (2010) Physico-Chemical and Toxicological Studies on Afzelia africana Seed and Oil. African Journal of Biotechnolo- 
gy, 9, 1959-1963. https://doi.org/10.5897/AJB09.965

[18] Ikwuagwu, O.E., Ononogbu, I.C. and Njoku, O.U. (2000) Production of Biodiesel Using Rubber Seed Oil. Industrial Crops and Products, 12, 27-63. https://doi.org/10.1016/S0926-6690(99)00068-0

[19] Coenen, J.W. (1976) Hydrogenation of Edible Oils. Journal of the American Oil Chemists' Society, 53, 382-389. https://doi.org/10.1007/BF02605727

[20] Kailas, M.T., Mahajan, D.T. and Masand, V.H. (2012) Physicochemical Properties of Soybean Oil and Their Blends with Vegetable Oils for the Evaluation of Lubrication Properties. Journal of Chemical, Biological and Physical Sciences, 3, 490-497.

[21] Amoo, I.A., Emenike, A.E. and Akpambang, V.O. (2008) Compositional Evaluation of Annonia cherimoya (Custard Apple) Fruit. Trends in Applied Sciences Research, 3, 216-220. https://doi.org/10.3923/tasr.2008.216.220

[22] Ikhuoria, E.U. and Maliki, M. (2007) Characterisation of Avocado Pear (Persea americana) African Pear (Dacryodes edulis) Extracts. African Journal of Biotechnology, 6, 950-952.

[23] Kochlar, S.L. (1986) Tropical Crops: A Textbook of Economic Botany. McMillian Publisher Ltd., London and Basingtone, 152-156.

[24] Nawar, W.W. (1996) Lipids. In: Fennema, O.R., Ed., Food Chemistry, Marcel Dekker, New York, 225-314.

[25] Marina, A.M., Che Man, Y.B. and Nazimah, S.A. (2009) Chemical Properties of Virgin Coconut Oil. Journal of American Oil Chemists' Society, 86, 302-307. https://doi.org/10.1007/s11746-009-1351-1

[26] SON Standard Organization of Nigeria (2000) Standard for Edible Refined Palm Oil and Its Processed Form. 2-5.

[27] NIS Nigeria Industrial Standard (1992) Standards for Edible Vegetable Oil. 5-12.

[28] Gan, H.L., Che Man, Y.B., Tan, C.P., NorAini, I. and Nazimah, S.A. (2005) Characterisation of Vegetable Oils by Surface Acoustic Wave Sensing Electronic Nose. Food Chemistry, 89, 507-518. https://doi.org/10.1016/j.foodchem.2004.03.005

[29] Caterm, N.B. and Margo, A.D. (2001) Behenic Acid Is a Cholesterol-Raising Saturated Fatty Acid in Humans. American Journal of Clinical Nutrition, 73, 41-44. https://doi.org/10.1093/ajen/73.1.41

[30] Hunter, J.E., Zhang, J. and Kris-Etherton, P.M. (2009) Cardiovascular Disease Risk of Dietary Stearic Acid Compared with Trans, Other Saturated, and Unsaturated Fatty Acids: A Systematic Review. American Journal of Clinical Nutrition, 91, 46-63. https://doi.org/10.3945/ajcn.2009.27661

[31] WHO (2003) Diet, Nutrition and the Prevention of Chronic Diseases. WHO Technical Report Series 916, Report of a Joint WHO/FAO Expert Consultation, World Health Organization, Geneva, 88.

[32] Benoit, S.C., Kemp, C.J., Elias, C.F., Abplanalp, W., Herman, J.P., Migrenne, S., Lefevre, A.L., Cruciani-Guglielmacci, C., Magnan, C., Yu, F., Niswender, K., Irani, B.G., Holland, W.L. and Clegg, D.J. (2009) Palmitic Acid Mediates Hypothalamic Insulin Resistance by Altering PKC- $\theta$ Subcellular Localization in Rodents. Journal of Clinical Investigation, 119, 2577-2587. https://doi.org/10.1172/JCI36714

[33] Pascual, G. (2016) Targeting Metastasis-Initiating Cells through the Fatty Acid Receptor CD36. Nature, 541, 41-45. https://doi.org/10.1038/nature20791

[34] Oomah, D.B., Ladet, S., Godfrey, V.D., Liang, J. and Giarard, B. (2000) Characteristics of Raspberry (Rubus idaeus L.) Seed Oil. Food Chemistry, 69, 187-193. 
https://doi.org/10.1016/S0308-8146(99)00260-5

[35] USDA (2016) Nutrient Data Laboratory Home Page. USDA National Nutrient Database for Standard Reference, Release 20. U.S. Department of Agriculture, Agricultural Research Service.

[36] Rudel, L.L., Kelly, K., Sawyer, J.K., Shah, R. and Wilso, M.D. (1998) Dietary Monounsaturated Fatty Acids Promote Aorti Atherosclerosis in LDL Receptor-Null ApoB100-Overexpressing Transgenic Mice. Arteriosclerosis, Thrombosis, and Vascular Biology, 18, 1818-1827. https://doi.org/10.1161/01.ATV.18.11.1818

[37] Ruggeri, S., Cappelloni, M., Gambelli, L., Nicoli, S. and Carnovale, E. (1998) Chemical Composition and Nutritive Value of Nuts Grown in Italy. Italian Journal of Food Science, 10, 243-252.

[38] Corbett, P. (2003) It Is Time for an Oil Change! Opportunities for High Oleic Vegetables Oils. Inform, 14, 480-481.

[39] Worthington, R.E. and Hammons, R.O. (1977) Variability in Fatty Acid Composition among Arachis Genotypes: A Potential Source of Product Improvement. Journal of the American Oil Chemists' Society, 54, 105-108. https://doi.org/10.1007/BF02912383

[40] Sanders, T.H., Lansden, J.A., Greene, R.L., Drexler, J.S. and Williams, E.J. (1992) Oil Characteristics of Peanut Fruit Separated by a Nondestructive Maturity Classification Method. Peanut Science, 9, 20-23. https://doi.org/10.3146/i0095-3679-9-1-6

[41] Feed Conversion Ratio (FCR) (2011) USAID Technical Bulletin. http://www.fintrac.com

[42] Fleming, S.E. and Lee, B. (1983) Growth Performance and Intestinal Transit Time of Rats Fed Purified and Natural Dietary Fibres. The Journal of Nutrition, 133, 592-601. https://doi.org/10.1093/jn/113.3.592

[43] Farran, M.T., Halaby, W.S., Barbour, G.W., Uwayjan, M.G., Sleiman, F.T. and Ashkarian, V.M. (2005) Effects of Feeding Ervil (Vicia ervilia) Seeds Soaked in Water or Acetic Acid on Performance and Internal Organ Size of Broilers and Production and Egg Quality of Laying Hens. Poultry Science, 84, 1723-1728.

https://doi.org/10.1093/ps/84.11.1723

[44] Lawn, R.M. (1992) Lipoprotein A in Heart Disease. Scientific American, 262, 26-32. https://doi.org/10.1038/scientificamerican0692-54

[45] Adedeji, A.L., Akintola, A.O., Oyewopo, A.O., Omotoso, E.O. and Badmus, J.A. (2008) Effects of Three Nigerian Stable Oils on the Plasma Lipid Profile of Wistar Rats. Research Journal of Medical Sciences, 2, 193-196.

[46] Getz, G.S. and Reardon, C.A. (2006) Diet and Murine Atherosclerosis. Arteriosclerosis, Thrombosis, and Vascular Biology, 26, 242-249. https://doi.org/10.1161/01.ATV.0000201071.49029.17

[47] Ohtani, H., Hayashi, K., Hirata, Y., Dojo, S., Nakashima, K., Nishio, E., Kurushima, H., Saeki, M. and Kajiyama, G. (1990) Effects of Dietary Cholesterol and Fatty Acids on Plasma Cholesterol Level and Hepatic Lipoprotein Metabolism. The Journal of Lipid Research, 31, 1413-1422.

[48] Tishinsky, J.M. (2013) Modulation of Adipokines by $n-3$ Polyunsaturated Fatty Acids and Ensuing Changes in Skeletal Muscle Metabolic Response and Inflammation. Applied Physiology, Nutrition, and Metabolism, 38, 361. https://doi.org/10.1139/apnm-2012-0447

[49] Choi, Y., Ahn, C., Rhee, H., Choe, M., Kim, C. and Kim, J. (1993) Comparative Effects of Dietary Palm Oil, Perilla Oil, and Soybean Oil on Lipid Profiles in Diffe- 
rently Aged Rats Fed on Hypercholesterolemic Diets. Bioscience, Biotechnology, and Biochemistry, 57, 65-68. https://doi.org/10.1271/bbb.57.65

[50] Ramachandran, D.H., Narasimhamurthy, K. and Raina, P.L. (2003) Modulation of Cholesterol Induced Hypercholesterolemia through Dietary Factors in Indian Desert Gerbils (Meriones hurrianae). Nutrition Research, 23, 245-256. https://doi.org/10.1016/S0271-5317(02)00517-1

[51] Almario, R.U., Vonghavaravat, V., Wong, R. and Kasim-Karakas, S.E. (2001) Effects of Walnut Consumption on Plasma Fatty Acids and Lipoproteins in Combined Hyperlipidemia. American Journal of Clinical Nutrition, 74, 71-79. https://doi.org/10.1093/ajcn/74.1.72

[52] Fashing, P., Ratheiser, K., Waldhausl, W., Rohac, M., Osterrode, W., Nowotny, P. and Vierphapper, H. (1991) Metabolic Effects of Fish-Oil in Patients with Impaired Glucose Tolerance. Diabetes, 40, 583-589. https://doi.org/10.2337/diab.40.5.583

[53] Lichtenstein, A.H., Matthan, N.R., Jalbert, S.M., Resteghini, N.A., Schaefer, E.J. and Ausman, L.M. (2006) Novel Soybean Oils with Different Fatty Acid Profiles Alter Cardiovascular Disease Risk Factors in Moderately Hyperlipidemic Subjects. The American Journal of Clinical Nutrition, 84, 497-504. https://doi.org/10.1093/ajcn/84.3.497

[54] Babalola, T.O. and Apata, D.F. (2011) Chemical and Quality Evaluation of Some Alternative Lipid Sources for Aqua Feed Production. Agriculture and Biology Journal of North America, 2, 935-943. https://doi.org/10.5251/abjna.2011.2.6.935.943

[55] Sena, C.M., Nunes, E., Louro, T., Proença, T., Fernandes, R., Boarder, M.R. and Seiça, R.M. (2008) Effects of $\alpha$-Lipoic Acid on Endothelial Function in Aged Diabetic and High-Fat Fed Rats. British Journal of Pharmacology, 153, 894-906. https://doi.org/10.1038/sj.bjp.0707474 